\title{
Short Review: Cu Catalyst for Autothermal Reforming Methanol for Hydrogen Production
}

\author{
Ho-Shing Wu ${ }^{1}$, and Donny Lesmana ${ }^{1,2}$ \\ ${ }^{1}$ Department of Chemical Engineering and Material Science, Yuan-Ze University, 135 Yuan Tung \\ Road, Chung Li, Taoyuan, 32003, Taiwan \\ ${ }_{2}^{2}$ Department of Chemical Engineering, Faculty of Engineering, University of Lampung, 1 Soemantri \\ Brojonegoro, Rajabasa, Bandar Lampung, 35145, Indonesia
}

Received: 3rd January 2012; Revised: 23rd February 2012; Accepted: 28th February 2012

\begin{abstract}
Hydrogen is a promising alternative energy sources, hydrogen can be used in fuel cell applications to producing electrical energy and water as byproduct. Therefore, fuel cell is a simple application and environmentally friendly oriented technology. Recent years various methods have been conducted to produce hydrogen. Those methods are derived from various sources such as methanol, ethanol, gasoline, hydrocarbons. This article presents a brief review a parameter process of that affects in autothermal reforming methanol use $\mathrm{Cu}$-based catalysts for production of hydrogen. Copyright (C) 2012 BCREC UNDIP. All rights reserved.
\end{abstract}

Keywords: Authothermal; Methanol; Reforming; Hydrogen; Cu; Fuel Cell

How to Cite: H.S. Wu, and D. Lesmana. (2012). Short Review: Cu Catalyst for Autothermal Reforming Methanol for Hydrogen Production. Bulletin of Chemical Reaction Engineering \& Catalysis, 7 (1): 27-42

Permalink: http://ejournal.undip.ac.id/index.php/bcrec/article/view/1284

\section{Introduction}

The growing world population has had a large effect on the demand for energy. To date, fossil fuels have been used as the main energy sources to support such demand. Unfortunately, fossil fuel reserves are expected to last no longer than 50-100 years [1]. The shortage of energy is thus becoming an important problem for mankind, prompting worldwide searches for alternative energy [1,2].

Environmental pollution became a major topic in recent years. Emission from motor vehicles and electric power generation plants are two of the largest sources of air pollution [3]. For controlling emissions from internal combustion engines [4] and high Efficient [5] are of utmost importance to

\footnotetext{
* Corresponding Author

E-mail: cehswu@saturn.yzu.edu.tw (Ho-Shing Wu)
}

search alternative power sources for vehicles.

Recent global energy shortage and more stringent emission regulations have stimulated research and development in fuel cell area [7]. Hydrogen fuel cell seems to be a promising solution to these global environmental and energy problems as using hydrogen in fuel cells produces useful energy at high efficiencies and generates only heat and water as emissions [6].

In this future, hydrogen is to become a major source of energy [10], fuel [11], an alternative source of energy [12], an important chemical material that is utilize in large amounts in synthetic chemical industries [8], and raw materials for petroleum and petrochemical industries [9].

Hydrogen has potential for use as a localized energy source to replace batteries inside electronic devices or to power vehicles [13] and used for 
energy purposes in fuel cells is a topic of large and growing interest [14]. Hydrogen is produced from various energy sources, stored, transported and used in industries, homes, automobiles, airplanes and factories or used as electricity generations, and will be used more and more if the research and development of it, is continued [10].

The interest on fuel cells has increased, however the main difficulty on hydrogen utilization is about production cost, in this context, a cheaper production alternative could make viable the hydrogen utilization in fuel cells [15]. The production of hydrogen as a fuel from a suitable carrier is a necessary step in light of the difficulties faced in hydrogen transport and storage [14].

This work summarizes about the fuel cell and hydrogen as a fuel, include the latest developments of hydrogen production from several authors. In each section will describe some of the results of previous studies on the production of hydrogen from autothermal reforming of methanol use $\mathrm{Cu}$-based catalyst, and process parameter that influences for this reaction .

\section{Fuel Cell}

Fuel cells are one of the most promising energy conversion devices due to their high intrinsic efficiency and ultra low emissions [20]. Fuel cell technology is rapidly on the rise. With an increased demand for fuel and energy efficiency over the modern combustion engine, fuel cells are a viable alternative [21].

Fuel cell by definition is an electrical cell, which unlike storage cells could be continuous feed with a fuel so that the electrical power output is sustained indefinitely [16]. Fuel cells can also be used to provide power for home, car, machine in plant, by producing electricity and significant amounts of waste heat.

Due to thermodynamic limitations, the efficiency of a typical combustion engine is usually less than $30 \%$, but a fuel cell can reach above $80 \%$ [2]. Fuel cell is a clean burning and highly reactive fuel that offers high thermal efficiencies of $35-45 \%$ in comparison with $25-30 \%$ typical of normal petroleum fueled engines. Therefore, under development in an effort to reduce $\mathrm{CO}_{2}$ emissions that accelerate global warming [22].

Fuel cell powered electric vehicles and power plants using hydrogen as fuel [23]. Fuel cell unit generates electrical energy from an electrochemical reaction of hydrogen with oxygen, yielding an environmentally benign by product, water [1]. Fuel cells work by absorbing oxygen and hydrogen gases to generate chemical reactions, and the products of the reactions are water and electricity. Oxygen can be absorbed directly from the atmosphere due to its abundance in the atmosphere. However, because hydrogen is less abundant content in the atmosphere, a mechanism for supplying hydrogen must be developed [2], and hydrogen are extremely difficult to store [18].

Fuel Cell reaction as a follow [24]:

Anode Reaction : $2 \mathrm{H}_{2}=>4 \mathrm{H}^{+}+4 \mathrm{e}$

Overall Cell Reaction: $\mathrm{O}_{2}+4 \mathrm{H}^{+}+4 \mathrm{e}^{-}=>2 \mathrm{H}_{2} \mathrm{O}$

Overall Cell Reaction: $2 \mathrm{H}_{2}+\mathrm{O}_{2}=>2 \mathrm{H}_{2} \mathrm{O}$

Fuel cells have been designed that can directly oxidize fuels such as methane, methanol, dimethylether, etc [25]. The permeable membrane was between anode and cathode. After hydrogen and oxygen would reach fuel cell of anode and cathode, respectively and thus the hydrogen atom of anode would be decomposed to form hydrogen protons and electrons by catalysis. Finally, hydrogen protons have been attracted into other side membrane by oxygen, and the electron that

Table 1. Data of Different type of Fuel Cell

\begin{tabular}{|c|c|c|c|}
\hline $\begin{array}{l}\text { Fuel Cell } \\
\text { Type }\end{array}$ & $\begin{array}{l}\text { Mobile } \\
\text { ion }\end{array}$ & $\begin{array}{l}\text { Operating } \\
\text { Tempera- } \\
\text { ture }\end{array}$ & $\begin{array}{c}\text { Applications and } \\
\text { notes }\end{array}$ \\
\hline$(\mathrm{AFC})$ & $\mathrm{OH}^{-}$ & $50-200^{\circ} \mathrm{C}$ & $\begin{array}{l}\text { Used in space vehi- } \\
\text { cles, e.g. Apollo, } \\
\text { Shuttle. }\end{array}$ \\
\hline (PEMFC) & $\mathrm{H}^{+}$ & $30-100^{\circ} \mathrm{C}$ & $\begin{array}{l}\text { Vehicles, mobile } \\
\text { applications, and } \\
\text { for lower power } \\
\text { CHP systems. }\end{array}$ \\
\hline (DMFC) & $\mathrm{H}^{+}$ & $20-90{ }^{\circ} \mathrm{C}$ & $\begin{array}{l}\text { Suitable for port- } \\
\text { able electronic sys- } \\
\text { tems of low power, } \\
\text { running for long } \\
\text { times. }\end{array}$ \\
\hline (PAFC) & $\mathrm{H}^{+}$ & $\sim 220^{\circ} \mathrm{C}$ & $\begin{array}{l}\text { Large numbers of } \\
200-\mathrm{kW} \text { CHP sys- } \\
\text { tems in use. }\end{array}$ \\
\hline (MCFC) & $\mathrm{CO}_{3}{ }^{2-}$ & $\sim 650^{\circ} \mathrm{C}$ & $\begin{array}{l}\text { Suitable for me- } \\
\text { dium- to large-scale } \\
\text { CHP systems, up to } \\
\text { MW capacity. }\end{array}$ \\
\hline (SOFC) & $\mathrm{O}^{2-}$ & $500-1000 \circ \mathrm{C}$ & $\begin{array}{l}\text { Suitable for all } \\
\text { sizes of CHP sys- } \\
\text { tems, } 2 \mathrm{~kW} \text { to multi- } \\
\text { MW. }\end{array}$ \\
\hline
\end{tabular}

Rewrite from Fuel Cells System Explained book, page 152003 [27] 
would produce electric current by outside-circuit. The hydrogen protons, electrons and oxygen are transformed into water molecule by using cathode catalyst. Hence, water is the only product waste [24].

Fuel cells have difference electrode that would be several kinds of fuel cell. Generally, it has five types such as Alkaline (AFC), Phosphate Fuel Cell (PAFC), Melt Carbonate Fuel Cell (MCFC), Solid Oxide Fuel Cell (SOFC) and Proton Exchange Membrane Fuel Cell (PEMFC) [26] as found in Table 1.

Until now fuel cell still expensive to produce and electrical energy that produce still low voltage. Hydrogen as a fuel still has any problem in a production, because still produce harmful exhaust gases such as CO. After hydrogen is generated then hydrogen must be collected and stored, until recently some researchers are still conducting research on the proper mix of materials as construction materials for hydrogen storage, and still not found the right method to transport and distribute hydrogen, because hydrogen is explosive, and hydrogen can cause a number corrosion problem.

\section{Hydrogen Production}

There were six types of methods to produce hydrogen for different source feedstock:

\subsection{Steam reforming}

Hydrogen production from hydrocarbon steam reforming is a cost-effective method in providing hydrogen for fuel cells [28]. Steam reforming processes using the steam reforming to produce hydrogen from methane, methanol and other carbohydrate [24]. Reactant is mixed with steam in the presence of a base metal catalyst to produce hydrogen and carbon monoxide.

\subsection{Electrolysis}

Hydrogen produced from the electrolysis of water in electrolysers. Electrolysers use electricity to divide water $\left(\mathrm{H}_{2} \mathrm{O}\right)$ into hydrogen and oxygen [27]. Conventional water electrolysis, such as an alkaline water electrolysis, high-pressure electrolysis, and solid polymer electrolyte water electrolysis, is basically applied to produce hydrogen if a cheap source of electricity is available. In the alkaline water electrolysis, the cells use aqueous solutions of $\mathrm{KOH}, \mathrm{NaOH}$ or $\mathrm{NaCl}$ as the electrolyte. This technology is well developed but the overall hydrogen production efficiency is too small, about $27 \%$ [29].

Water electrolysis is technologically simple, environmentally clean and generates very high purity gases (hydrogen and oxygen) from water. Unlike other technologies, water electrolysis does not require large, centralized plants and the cost of hydrogen production scales well from the larger to smaller systems. In an alkaline medium, the half reaction at the anode is [30].

$$
4 \mathrm{OH}^{-} \rightarrow \mathrm{O}_{2}+2 \mathrm{H}_{2} \mathrm{O}+4 \mathrm{e}^{-}
$$

One of the major limitations of water electrolysis for hydrogen production is the poor kinetics of oxidation of hydroxyl ions to oxygen at anode [30].

\subsection{Steam electrolysis}

Steam electrolysis is a variation of the conventional electrolysis process. Some of the energy needed to split the water is added as heat instead of electricity. Water decomposes into hydrogen and oxygen.

The high-temperature steam electrolysis offers a promising method for highly efficient hydrogen production. Operation at high temperatures reduces the electrical energy requirement for the electrolysis and also increases the efficiency of the power generating cycle. In addition, hightemperature systems can promote electrode activity and lessen the over potential. Therefore, it is possible to increase the electric current density and consequently decrease the polarization losses at high temperatures, which improves the hydrogen production density and the electrolysis efficiency [31].

\subsection{Thermochemical water-splitting}

Hydrogen could be produced by thermochemical water-splitting, a chemical process that effects the multistep decomposition of water. Water and heat are the inputs. Hydrogen and oxygen are the only outputs. The other chemicals and reagents are recycled in a closed cycle [32]. Heat can be produced by chemical, solar, nuclear. A thermochemical cycle effects the multi-step decomposition of water into hydrogen and oxygen using only heat [33].

Solar thermochemical water-splitting, in which water is used as the chemical source for hydrogen production and high temperature solar heat is used as the energy source, provides one of the most promising ways to realize hydrogen production from water [34]. Because it's much more environmentally since hydrogen produced by thermo-chemical water-splitting does not contain 
contaminants, it could be used directly in fuel cells [32].

In addition to reforming and thermochemical water-splitting, electrolysis produces pure hydrogen. But this latter method suffers from thermodynamic inefficiencies. The efficiency of electrolysis is currently about $70 \%$ and the efficiency of heat conversion to electricity is usually 33\% (with current technology nuclear heat). Thus, the current combined efficiency does not exceed $20-25 \%$ [32].

\subsection{Photocatalyst processes}

Production of electricity and hydrogen by photocatalytic degradation of organic wastes in a photoelectrochemical (PEC) cell is an attractive project with double environmental benefit: waste material can be consumed and solar radiation can be converted into useful forms of energy, such as electricity and hydrogen [35].

Photoelectrochemical production of hydrogen is produce in a PEC cell. The following three components are the main components of a PEC cell: (a) the anode electrode, which carries the photocatalyst and thus it is usually named "Photo anode". When the photo-catalyst is an n-type semiconductor, which is almost the exclusive case, the photo anode produces electrons, it is the negative electrode, Oxidation reactions take place at the photo anode, (b) the cathode electrode, which carries the electro catalyst, material, which facilitates transfer of electrons from the cathode to the liquid phase. Reductive interactions take place at the (dark) cathode, for example, reduction of hydrogen ions to molecular hydrogen, (c) The electrolyte, which is added in order to increase conductivity and define the $\mathrm{pH}$ [35]. Thus the photocatalytic and photoelectrochemical routes are similar. The only difference is that, in the second case, the site of molecular hydrogen evolution is spatially separated from the site of target substance oxidation. By inversing this statement, we may accordingly say that a photocatalyst with deposited metal is a miniature photoelectrochemical cell [36].

Photoelectrochemical processes use two types of electrochemical systems to produce hydrogen. One uses soluble metal complexes as a catalyst such a $\mathrm{TiO}_{2}, \mathrm{La}_{2} \mathrm{Ti}_{2} \mathrm{O} 7, \mathrm{CdS} / \mathrm{TiO}_{2}$, and $\mathrm{Fe}_{2} \mathrm{O}_{3}$ [86], while the other uses semiconductor surfaces such as non-oxide semiconductors, e.g., $\mathrm{Si}, \mathrm{InP}, \mathrm{CdTe}$, GaAs, etc [37].

The photocatalytic process has been criticized as being uneconomical compared with other hydrogen production systems, due to its inherently low efficiency and other limitations [38].

\subsection{Photobiological processes}

Photobiological is production hydrogen from renewable source such as solar heat from sunlight and water. Hydrogen-production includes processes such as: (i) direct biophotolysis of water by microalgae and cyanobacteria, (ii) photofermentative nitrogen fixation and the attendant hydrogen production by photosynthetic bacteria, (iii) non-photosynthetic hydrogen production from organic compounds by obligate anaerobic bacteria, (iv) nitrogen fixing fermentative bacteria [39].

These processes can be beneficial in two ways: firstly by removing the green house gases (mostly $\mathrm{CO}_{2}$ ) which are responsible for global-warming and production of nonpolluting, renewable potential energy carrier (biophotolysis by green algae and cyanobacteria) and secondly using waste materials that potentially create ecological hazards, as substrate (photofermentation by photosynthetic bacteria) [40].

Photobiological hydrogen production has several limitations and the yield is very low compared to thermochemically and electrochemically produced hydrogen [82], relatively low efficiency of photosynthesis in practice [41].

One of the weakness of hydrogen production from raw water, is a must keep the clean process from initial to the end of process, because water contains corrosive substances. So it can increased energy used in the process.

Hydrogen production based on biology process is very interesting to study further, but until now, the biological process is still an expensive process, because it requires expensive enzymes, bacteria, and not a short process time, and requires the separation of the product at the end of the process.

Steam reforming is a more economical process than the others, because less production cost, short time in a process, not used high pressure steam, high selectivity and less exhaust emissions.

\section{Steam Reforming}

Conventional methods for hydrogen production are based on gasoline [29-31], natural gas [42-44], methanol $[45,23,22,46-51,52]$, ethanol $[12,15$, 53, 54-58], and a renewable raw material [59-63]. 
An important issue in gasoline reforming is the deactivation of the catalyst by coke formation or by sulfur compounds present in the feed. Gasoline contains different types of sulfur compounds (thiophene, benzothiophene) at a concentration of a few ppm. These sulfur compounds can interact with the catalyst surface and may alter the chemical and structural properties of the active sites, which results in the deactivation of the noble metal catalyst [64].

The development of onboard reformer or partial oxidation processor of gasoline to hydrogen and $\mathrm{CO}_{2}$ inevitably release a large quantity of $\mathrm{CO}_{2}$ and an unacceptable level of $\mathrm{CO}$ [65].

Natural gas is the resource most commonly used for hydrogen production. Typically, natural gas (which consists mainly of methane) is converting to hydrogen through steam methane reforming (SMR) [42]. Natural gas is clean hydrocarbon fuel, abundant, and well distributed, is considering one of the ideal fuels for hydrogen source for fuel-cell stationary applications [44]. However, liquid feedstocks are used. In particular, carbon deposition and poisoning by sulfur and other electronegative atoms $(\mathrm{Cl}, \mathrm{P})$ determine loss of catalyst activity, especially when petroleumderived liquid fuels are used [43].

Ethanol is a promising source of hydrogen as it is a renewable source when obtained from biomass [54]. Ethanol also capable to produce hydrogen from steam-reform, its advantages are clear: ethanol is liquid, has low toxicity and its production is simple and cheap [15]. Direct production of $\mathrm{H}_{2}$ from carbohydrates catalytically has been demonstrated, but the process requires long reaction times and has shown only $\sim 50 \%$ selectivity to $\mathrm{H}_{2}$ from glucose [67].

Among the hydrocarbon fuels examined. Methanol is one of the best source [17] and promising candidate fuels [20], Methanol is a renewable resource, low boiling point, high $\mathrm{H} / \mathrm{C}$ ratio[17], safe handling/storage materials [45], sulfur-free, can be activated at relatively low temperature (under $300 \circ \mathrm{C}$ ) [10], high ratio of hydrogen [24]. Methanol also offers a high conversion rate and produces fewer by-products, other hydrocarbon fuels [2].

Methanol has high $\mathrm{H} / \mathrm{C}$ ratio and no $\mathrm{C}-\mathrm{C}$ bonds, hence minimizing the risk for coke formation. Moreover, as methanol can be produce from renewable sources, its reforming does not contribute to a net addition of $\mathrm{CO}_{2}$ to the atmosphere [66]. The decomposed methanol is a cleaner and more efficient fuel than gasoline and undecomposed methanol for internal combustion engines of automobiles [3].
Methanol, compared to natural gas or other hydrocarbons, is a more efficient energy source to produce hydrogen used in fuel cells [68]. The methane reforming reaction requires a huge amount of energy, 973-1273 K, while the ethanol has been used in various applications such as gasohol and food production. Methane and ethanol have been widely used as energy resources, so there is no need to spend significant amount of energy to convert methane and ethanol to be hydrogen [1].

For producing hydrogen on-board due to the following advantages: mild reforming reaction conditions; no needs for desulfurization; no needs for pre-reforming; no serious carbon formation problem. Under ambient condition, liquid methanol has a high volumetric energy density. Many studies have been conducted on steam reforming of methanol [20].

Hydrogen production from methanol is possible through several process alternatives [20,69]:

\subsection{Methanol decomposition (MD)}

$\mathrm{CH}_{3} \mathrm{OH} \rightarrow \mathrm{CO}+2 \mathrm{H}_{2} \quad\left(\Delta \mathrm{H}^{\circ}=+92.0 \mathrm{~kJ} / \mathrm{mol}\right)$

The decomposition reaction is a strong endothermic reaction The process yields high CO contents [70], Hence, this reaction was unsuitable for the PEM fuel cell application [24], because carbon monoxide produced is Apart from being harmful to health, an atmospheric pollutant and a poison for the fuel cell [71].

\subsection{Methanol steam reforming (SRM)}

$\mathrm{CH}_{3} \mathrm{OH}+\mathrm{H}_{2} \mathrm{O} \rightarrow \mathrm{CO}_{2}+3 \mathrm{H}_{2}\left(\Delta \mathrm{H}^{\circ}=+49.4 \mathrm{~kJ} / \mathrm{mol}\right)$

Steam reforming involves the reaction of steam with the fuel in the presence of a catalyst to produce $\mathrm{H}_{2}$ and $\mathrm{CO}$. Since steam reforming is endothermic, some of the fuel must be burned and the heat transferred to the reformer via heat exchangers [72]. Yields $\mathrm{CO}_{2}$ as the major byproduct and can produce a high content, up to $75 \%$ on a dry basis, which makes it very favorable for fuel cell applications [70]. Unfortunately, a considerable amount of $\mathrm{CO}(>100 \mathrm{ppm})$ as a byproduct is produced during the reaction [23].

SRM shows the highest hydrogen production efficiencies [5], however a limitation is the endothermicity of the reaction. Moreover, slow heat transfer in the catalytic bed results in slow response at start-up. A promising option that offers good heat transfer characteristics is the combination of endothermic steam reforming with 
Table 2. Summary of production hydrogen research using methanol with different method of reaction

\begin{tabular}{|c|c|c|c|c|c|c|c|}
\hline Reaction & $T_{\text {reaction }}\left({ }^{\circ} \mathbf{C}\right)$ & $\mathrm{X}_{\mathrm{MeOH}}(\%)$ & $\begin{array}{c}\text { CO } \\
\text { yield } \\
\text { (ppm) }\end{array}$ & $\begin{array}{l}\text { CO selec- } \\
\text { tivity (\%) }\end{array}$ & $\begin{array}{c}\text { Rate of } \mathrm{H}_{2} \\
\text { production } \\
\left(\mathrm{cm}^{3} \mathrm{~g}^{-1}\right. \\
\left.\text { min }^{-1}\right) \\
\end{array}$ & $\begin{array}{c}S\left(\mathbf{H}_{2}\right) \\
(\%)\end{array}$ & $\begin{array}{c}\mathrm{H}_{2} \text { yield } \\
\text { (\%) }\end{array}$ \\
\hline SRM [1] & 250 & - & - & - & - & - & 28 \\
\hline $\mathrm{MD}[3]$ & 275 & 63 & $51.6^{\mathrm{b}}$ & 81.6 & - & 91.6 & 57.9 \\
\hline ATRM [20] & 230 & 98.4 & 3642 & - & - & - & 49.4 \\
\hline POM [22] & 200 & $40-60$ & - & - & - & $>90$ & - \\
\hline SRM [23] & 250 & 95.5 & - & 0.14 & - & 99.9 & - \\
\hline ATRM [43] & 250 & 90 & - & 3.8 & - & - & - \\
\hline ATRM [45] & 270 & 98 & - & $0.1-1.2$ & $2.16^{\mathrm{d}}$ & - & - \\
\hline SRM [46] & 250 & $83^{\mathrm{a}}$ & - & - & - & $94^{\mathrm{c}}$ & - \\
\hline SRM [49] & 260 & 90 & - & $0.06^{c}$ & $244^{\mathrm{e}}$ & - & - \\
\hline SRM [51] & 250 & 88.7 & - & 0.5 & - & - & - \\
\hline SRM [70] & 235 & - & - & - & - & - & $50-74$ \\
\hline SRM [73] & 300 & 95.0 & - & 3.4 & 32.1 & 96.6 & - \\
\hline ATRM [74] & 230 & 85 & - & - & - & 27 & - \\
\hline SRM [77] & $160-350$ & - & - & - & $816^{\mathrm{f}}$ & 99 & - \\
\hline MD [78] & 315 & 97 & - & 95 & - & - & - \\
\hline SRM [78] & 255 & 98 & - & 5 & - & - & - \\
\hline SRM [79] & 230 & 96 & - & 86 & - & - & - \\
\hline SRM [80] & 240 & 97 & $<500$ & - & - & - & $>50$ \\
\hline
\end{tabular}

$\mathrm{a}=\mathrm{mol} \% ; \mathrm{b}=\% ; \mathrm{c}=\mathrm{mol} \% ; \mathrm{d}=\mathrm{l} / \mathrm{h} ; \mathrm{e}=\left(\mathrm{mmol} \mathrm{s}^{-1}\right.$ kgcat $\left.^{-1}\right) ; \mathrm{f}=\left(\mathrm{cm}^{3} \mathrm{~g}^{-1} \mathrm{~h}^{-1}\right) ; \mathrm{MD}=$ Methanol Decomposition; $\mathrm{SRM}=$ Methanol steam reforming; $\mathrm{POM}=$ Partial Oxidation Methanol; ATRM =Autothermal Reforming Methanol

the exothermic combustion of part of methanol feed [73].

\subsection{Partial oxidation methanol (POM)}

$$
\begin{array}{r}
\mathrm{CH}_{3} \mathrm{OH}+0.5 \mathrm{O}_{2} \rightarrow \mathrm{CO}_{2}+2 \mathrm{H}_{2}\left(\Delta \mathrm{H}^{\circ}=-192.2\right. \\
\mathrm{kJ} / \mathrm{mol}) \\
\mathrm{CH}_{3} \mathrm{OH}+0.25 \mathrm{O}_{2} \rightarrow 0.5 \mathrm{CO}_{2}+0.5 \mathrm{CO}+2 \mathrm{H}_{2} \\
\left(\Delta \mathrm{H}^{\circ}=-50.8 \mathrm{~kJ} / \mathrm{mol}\right)
\end{array}
$$

Partial oxidation reaction is a highly exothermic process [73] and needs external cooling in general [5].

Partial oxidation involves the reaction of oxygen with fuel to produce $\mathrm{H}_{2}$ and $\mathrm{CO}$ [72]. The system can only deliver $66 \%$ hydrogen when pure oxygen and $41 \%$ when air is use to supply the oxygen [70].

Partial oxidation can be conduct with a catalyst (catalytic partial oxidation) or without a catalyst (non-catalytic partial oxidation). The reaction rates are much higher for partial oxidation than for steam reforming, but the $\mathrm{H}_{2}$ yield per carbon in the fuel is lower. Non-catalytic partial oxidation requires reaction temperatures above $1000{ }^{\circ} \mathrm{C}$ to achieve rapid reaction rates, some of the fuel must be combusted because the amount of heat generated by the reaction is not sufficient to preheat the feed to achieve optimal rates [72].

\subsection{Autothermal reforming of methanol (ATRM)}

$$
\mathrm{CH}_{3} \mathrm{OH}+(1-\alpha) \mathrm{H}_{2} \mathrm{O}+0.5 \alpha \mathrm{O}_{2} \rightarrow \mathrm{CO}_{2}+(1-\alpha) \mathrm{H}_{2}
$$$$
\left(\Delta \mathrm{H}^{\circ}=49-242 . \mathrm{a} \mathrm{kJ} / \mathrm{mol}\right)
$$

Autothermal reforming involves the reaction of oxygen, steam, and fuel to produce $\mathrm{H}_{2}$ and $\mathrm{CO}_{2}$, and can be viewed as a combination of partial oxidation and steam reforming [72]. These systems can be very productive, fast starting and compact, since the exothermic partial oxidation reaction can supply heat to steam reforming reaction directly [9].

Autothermal reforming uses the energy produced from partial oxidation to supply the endothermic, steam-reforming reaction, and thus can be run adiabatically. This process has not been extensively studied, but initial results indicate low 
carbon monoxide yield and high hydrogen concentration in the products [74]. Autothermal reforming promises better dynamic response than both of the before mentioned reforming processes [5].

An ideal method to produce hydrogen with lower amount of $\mathrm{CO}$ from steam reforming of methanol greatly requires a high performance catalyst, which must be highly active and selective for hydrogen production and also stable for a long period in a continuous operation. Now the most widely used catalysts for this reaction are copper containing catalysts since copper has been found to be high activity and selectivity for hydrogen production [23]. In order to reduce the $\mathrm{CO}$ content in the feed gas obtained from fuel reforming to a tolerable level (less than $10 \mathrm{ppm}$ ), it is necessary to find a more active and more effective catalyst [21].

\subsection{Water gas shift}

Steam and combined reforming are commonly operated with an excess of steam, 20-30\%. The excess steam is mainly present in order to reduce the carbon monoxide content [69] and to enrich hydrogen in the reformate stream [75] by inducing the water-gas shift (WGS) reaction in the reformer.

$$
\mathrm{CO}+\mathrm{H}_{2} \mathrm{O} \rightarrow \mathrm{CO}_{2}+\mathrm{H}_{2} \quad\left(\Delta \mathrm{H}^{\circ}=-41.1 \mathrm{~kJ} / \mathrm{mol}\right)
$$

The WGS reaction is a reversible, relatively slow and moderately exothermic reaction [75]. WGS is used for ammonia synthesis, to adjust the $\mathrm{H}_{2} / \mathrm{CO}_{2}$ ratio in the product gas from the steam reforming of hydrocarbons and to detoxify town gas [76].

The Autothermal reforming method is better than the other methods, Based on the reaction temperature is low, high methanol conversion and high yield of hydrogen. However weaknesses in the high yield of $\mathrm{CO}$ are produced.

Autothermal reforming also called Oxidative steam reforming (OSR), which is a combination of Methanol steam reforming and Partial Oxidation Methanol [81]. An extremely high rates of hydrogen production were observed in the oxidative steam reforming of methanol [82]. In recent years, the catalytic ATR process has received much research and Development attention as a viable process for hydrogen generation for fuel-cell systems because it offers advantages of simpler design (smaller and lighter unit), lower operating temperature (easier startup and a wider choice of materials), and flexible load following characteristic as compared to the steam reforming process. It also has higher energy efficiency than the partial oxidation process [44].

In OSR, the exothermic partial oxidation of methanol supplies the heat energy that is required for internal endothermic steam reforming. The overall heat of reaction depends on a (Eq. (9)), which is the molar ratio of oxygen to methanol and affects the hydrogen concentration. Furthermore, the reaction of $\mathrm{CO}$ with oxygen in OSR is expected to reduce the amount of $\mathrm{CO}$ by-product [83].

In the endothermic steam-reforming process heat is transferred across a heat-conducting boundary to support the reforming reaction between methanol and water. The rate of the process is usually limited by the rate of heat transfer across the boundary. Therefore, improvements to steam reforming are generally sought in designing reactors having low heat resistance and intimate contact between the reforming and the heating zones, such as micro channel technology. On the other hand, in the OSR process heat release is part of the overall reforming process, such that the heat transfer limitation is removed allowing for a many-fold increase in the reaction rate [82].

Methanol autothermal reforming reaction (ATR) has a net reaction enthalpy change of zero which is a combination of the endothermic steamreforming reaction and the exothermic partial oxidation reaction, thus a reactor for this process does not require any extra external heat after having attained reaction temperature [84].

\section{Process Parameter}

Process production of $\mathrm{H} 2$ on board a vehicle must meet several criteria. For instance, it must be compact and energy efficient, respond to transient behavior, and produce a reformatted with a high $\mathrm{H}_{2}$ content and extremely low $\mathrm{CO}$ level [66]. Maximizing $\mathrm{H}_{2}$ yield is the goal for increasing the efficiency of the process [82]. An ideal Product of OSR has only $\mathrm{H}_{2}$ and $\mathrm{CO}_{2}$. However, in an actual process OSR, CO will be formed in addition to $\mathrm{CO}_{2}$. Also methanol, oxygen and water may not be fully consumed in the reactor, and methane and other components may form as by-products [82]. Other byproducts such as formaldehyde, formic acid, methyl formate or dimethyl ether often formed by reactions of methanol [73]. 
Table 3. Effect different preparation method into physicochemical properties of $\mathrm{Cu}$ and $\mathrm{Zn}$ based catalysts .

\begin{tabular}{|c|c|c|c|c|c|c|}
\hline Catalyst & composition (wt \%) & $\begin{array}{l}\text { Preparation } \\
\text { method }\end{array}$ & $\begin{array}{c}\text { Pore vol- } \\
\text { ume }\left(\mathrm{cm}^{3}\right. \\
\left.\mathrm{g}^{-1}\right)\end{array}$ & $\begin{array}{c}\text { SBET } \\
\left(m^{2} g^{-1}\right)\end{array}$ & $\begin{array}{c}\mathrm{S}_{\mathrm{Cu}} \\
\left(\mathbf{m}^{2} \mathbf{g}^{-1}\right)\end{array}$ & $\begin{array}{l}\text { Cu disper- } \\
\text { sion }(\%)\end{array}$ \\
\hline $\mathrm{Cu} / \mathrm{ZnO} / \mathrm{Al}_{2} \mathrm{O}_{3}[4]$ & - & $\mathrm{I}$ & - & - & - & - \\
\hline $\mathrm{Cu} / \mathrm{CeO}_{2}[11]$ & 3.9 & $\mathrm{CP}$ & - & 96 & 101.6 & - \\
\hline $\mathrm{Cu} / \mathrm{ZnO}[11]$ & - & $\mathrm{AP}$ & - & 78 & 75.3 & - \\
\hline $\mathrm{Cu} / \mathrm{Zn}(\mathrm{Al}) \mathrm{O}[11]$ & - & $\mathrm{HC}$ & - & 114 & 80.8 & - \\
\hline $\mathrm{Cu} / \mathrm{Al}_{2} \mathrm{O}_{3}[11]$ & - & I & - & 157 & 73.7 & - \\
\hline $\mathrm{Cu} / \mathrm{CeO}_{2}[11]$ & - & I & - & 84 & 61.5 & - \\
\hline $\mathrm{Cu} / \mathrm{Zn} / \mathrm{Al}_{2} \mathrm{O}_{3}[24]$ & $15 / 15 / 5$ & $\mathrm{OCP}$ & 0.371 & 70.78 & - & 7.5 \\
\hline $\mathrm{Cu} / \mathrm{Zn} / \mathrm{ZrO}_{2}[24]$ & $15 / 15 / 5$ & $\mathrm{OCP}$ & 0.24 & 40.01 & - & 7.3 \\
\hline $\mathrm{Cu} / \mathrm{Zn} / \mathrm{CeO}_{2}[24]$ & $15 / 15 / 5$ & $\mathrm{OCP}$ & 0.2 & 36.7 & - & 6.4 \\
\hline $\mathrm{Cu} / \mathrm{Zn} / \mathrm{Cr}_{2} \mathrm{O}_{3}[24]$ & $15 / 15 / 5$ & $\mathrm{OCP}$ & 0.35 & 35.8 & - & 8.0 \\
\hline $\mathrm{Cu} / \mathrm{Zn} / \mathrm{Al}_{2} \mathrm{O}_{3} / \mathrm{Cr}_{2} \mathrm{O}_{3}[24]$ & $15 / 15 / 2.5 / 2.5$ & OCP & - & - & - & 8.5 \\
\hline $\mathrm{Cu} / \mathrm{Zn} / \mathrm{Al}[45]$ & $40 / 50 / 10$ & $\mathrm{~W}$ & 0.160 & 108 & - & - \\
\hline $\mathrm{Cu} / \mathrm{CeO}_{2} / \mathrm{Al}_{2} \mathrm{O}_{3}[46]$ & $(5.79 \mathrm{wt} \% \mathrm{Cu})$ & $\mathrm{CP}$ & - & - & 16.0 & 39.5 \\
\hline $\mathrm{Cu} / \mathrm{CeO}_{2} / \mathrm{Al}_{2} \mathrm{O}_{3}[46]$ & $(15,3 \mathrm{wt} \% \mathrm{Cu})$ & $\mathrm{CP}$ & - & - & 69.7 & 29.5 \\
\hline $\mathrm{Cu} / \mathrm{CeO}_{2} / \mathrm{Al}_{2} \mathrm{O}_{3}[46]$ & $(24.1 \mathrm{wt} \% \mathrm{Cu})$ & $\mathrm{CP}$ & - & - & 79.0 & 25.2 \\
\hline $\mathrm{Cu} / \mathrm{CeO}_{2} / \mathrm{Al}_{2} \mathrm{O}_{3}[46]$ & $(27.8 \mathrm{wt} \% \mathrm{Cu})$ & $\mathrm{CP}$ & - & - & 47.2 & 13.7 \\
\hline $\mathrm{Cu} / \mathrm{ZnO} / \mathrm{Al}_{2} \mathrm{O}_{3}[51]$ & $30 / 60 / 10$ & $\mathrm{CP}$ & - & - & 88.8 & 45.8 \\
\hline $\mathrm{Cu} / \mathrm{ZnO} / \mathrm{Al}_{2} \mathrm{O}_{3}[51]$ & $40 / 50 / 10$ & $\mathrm{CP}$ & - & - & 67.0 & 34.6 \\
\hline $\mathrm{Cu} / \mathrm{ZnO} / \mathrm{Al}_{2} \mathrm{O}_{3}[51]$ & $50 / 40 / 10$ & $\mathrm{CP}$ & - & - & 58.7 & 30.2 \\
\hline $\mathrm{Cu} / \mathrm{ZnO} / \mathrm{Al}_{2} \mathrm{O}_{3}[51]$ & $60 / 30 / 10$ & $\mathrm{CP}$ & - & - & 54.4 & 28.1 \\
\hline $\mathrm{Cu} / \mathrm{ZnO} / \mathrm{Al}_{2} \mathrm{O}_{3}[51]$ & $30 / 60 / 10$ & $\mathrm{CP}$ & - & - & 36.3 & 18.7 \\
\hline $\mathrm{Cu} / \mathrm{Zn} / \mathrm{Al}_{2} \mathrm{O}_{3}[80]$ & $15 / 15 / 5$ & $\mathrm{OCP}$ & - & 71 & 17.9 & 8.25 \\
\hline $\mathrm{Cu} / \mathrm{Zn} / \mathrm{Al}[87]$ & $30 / 30 / 40$ & $\mathrm{CP}$ & 0.26 & 92 & 18.3 & 9.4 \\
\hline $\mathrm{Cu} / \mathrm{Zn} / \mathrm{Al}[87]$ & $30 / 20 / 50$ & $\mathrm{CP}$ & 0.32 & 106 & 25.1 & 12.8 \\
\hline $\mathrm{Cu} / \mathrm{Zn} / \mathrm{Ce} / \mathrm{Al}[87]$ & $30 / 25 / 5 / 40$ & $\mathrm{CP}$ & 0.28 & 96 & 20.2 & 10.2 \\
\hline $\mathrm{Cu} / \mathrm{Zn} / \mathrm{Ce} / \mathrm{Al}[87]$ & $30 / 20 / 10 / 40$ & $\mathrm{CP}$ & 0.34 & 108 & 38.6 & 19.6 \\
\hline $\mathrm{Cu} / \mathrm{Zn} / \mathrm{Ce} / \mathrm{Al}[87]$ & $30 / 10 / 20 / 40$ & $\mathrm{CP}$ & 0.29 & 101 & 29.3 & 14.8 \\
\hline $\mathrm{CuO} / \mathrm{ZnO} / \mathrm{Al}_{2} \mathrm{O}_{3}[83]$ & $30 / 60 / 10$ & $\mathrm{CP}$ & - & 98.4 & 54.0 & 65.5 \\
\hline $\mathrm{CuO} / \mathrm{ZnO} / \mathrm{Al}_{2} \mathrm{O}_{3}[83]$ & $40 / 50 / 10$ & $\mathrm{CP}$ & - & - & 62.5 & 79.6 \\
\hline $\mathrm{CuO} / \mathrm{ZnO} / \mathrm{Al}_{2} \mathrm{O}_{3}[83]$ & $50 / 40 / 10$ & $\mathrm{CP}$ & - & - & 59.8 & 71.1 \\
\hline $\mathrm{CuO} / \mathrm{ZnO} / \mathrm{Al}_{2} \mathrm{O}_{3}$ [83] & $60 / 30 / 10$ & $\mathrm{CP}$ & - & - & 55.9 & 69.8 \\
\hline $\mathrm{CuO} / \mathrm{ZnO} / \mathrm{Al}_{2} \mathrm{O}_{3}[83]$ & $30 / 50 / 20$ & $\mathrm{CP}$ & - & 73.1 & 47.6 & 24.5 \\
\hline 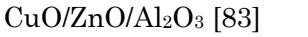 & $30 / 40 / 30$ & $\mathrm{CP}$ & - & 62.0 & 42.1 & 22.1 \\
\hline $\mathrm{ZnCr/Ti} \mathrm{[89]}$ & $20 \% \mathrm{ZnO}-\mathrm{ZnCr}_{2} \mathrm{O}_{4} / \mathrm{TiO}_{2}$ & WMP & $25.9^{b}$ & 4 & - & - \\
\hline \multirow{2}{*}{$\begin{array}{l}\mathrm{ZnCr} / \mathrm{Al}[89] \\
\mathrm{ZnCr} / \mathrm{Ce}[89]\end{array}$} & $20 \% \mathrm{ZnO}-\mathrm{ZnCr}_{2} \mathrm{O}_{4} / \mathrm{Al}_{2} \mathrm{O}_{3}$ & WMP & $7.8^{\mathrm{b}}$ & 126 & - & - \\
\hline & $20 \% \mathrm{ZnO}-\mathrm{ZnCr}_{2} \mathrm{O}_{4} / \mathrm{CeO}_{2}$ & WMP & $7.1^{\mathrm{b}}$ & 15 & - & - \\
\hline \multirow{2}{*}{$\begin{array}{l}\mathrm{ZnCr/Zr}[89] \\
\mathrm{ZnCr} / \mathrm{CeZr41}[89]\end{array}$} & $20 \% \mathrm{ZnO}-\mathrm{ZnCr}_{2} \mathrm{O}_{4} / \mathrm{ZrO}_{2}$ & WMP & $8.2^{\mathrm{b}}$ & 4 & - & - \\
\hline & $\begin{array}{c}20 \% \mathrm{ZnO}-\mathrm{ZnCr}_{2} \mathrm{O}_{4} / \mathrm{CO}_{2}-\mathrm{ZrO}_{2} \\
(\mathrm{Ce} / \mathrm{Zr}=4 / 1)\end{array}$ & WMP & $10.5^{b}$ & 11 & - & - \\
\hline $\mathrm{ZnCr}[89]$ & $\mathrm{ZnO}-\mathrm{ZnCr}_{2} \mathrm{O}_{4}$ & WMP & $9.9^{\mathrm{b}}$ & 6 & - & - \\
\hline
\end{tabular}

$\mathrm{b}=\mathrm{nm}$; $\mathrm{SBET}=\mathrm{BET}$ surface area; $\mathrm{SCu}=\mathrm{Cu}$ Surface area; CP: Co-precipitation; WMP: Wetness impregnation; I: Impregnation; $\mathrm{W}=$ Wash coat; OCP = Oxalic co-precipitation; AP: Aurichalcite precursor; HC: Hydrotalcite precursor

\subsection{Catalysts}

An ideal method to produce hydrogen with lower amount of $\mathrm{CO}$ from steam reforming of methanol greatly requires a high performance catalyst, which must be highly active, selective for hydrogen production, and stable for a long period in a continuous operation. Now the most widely used catalysts for this reaction are copper containing catalysts since copper has found to be high activity and selectivity for hydrogen production [23]. In order to reduce the $\mathrm{CO}$ content in the feed gas obtained from fuel reforming to a tolerable level (less than $10 \mathrm{ppm}$ ), it is necessary to find a more active and more effective catalyst [21]. Hydrogen produced from methanol via a catalytic reaction. Several catalysts were use to produce hydrogen by autothermal reforming reaction method.

Literature studies of Autothermal Reforming Methanol mainly focus on $\mathrm{Cu}-\mathrm{ZnO}$ based Catalysts [4,24,45,85,74,80,86,87,81], Another interesting catalyst for the ATRM reaction is $\mathrm{Pd} / \mathrm{ZnO}[19,88]$.

$\mathrm{Cu}$-based catalysts deactivate quickly and Pt- 
based catalyst has poor selectivity. Pd-Zn catalysts are extremely expensive, though they have a high activity and selectivity. Hence, they are not suitable for onboard production of hydrogen [84]. The $\mathrm{Cu}-\mathrm{Zn}$ based catalysts require a high operation temperature of 523-573 K to produce the effective hydrogen yield [1].

$\mathrm{Cu}$-based catalysts have comparatively low tolerance toward heat because maximum allowable operating temperature $\left(<300{ }^{\circ} \mathrm{C}\right)$ [85]. The rapid deactivation of $\mathrm{Cu}-\mathrm{ZnO}$ based catalysts by sintering of the metal at temperatures above $300{ }^{\circ} \mathrm{C}$, is a barrier to its practical application in the OMR process [88]. In order to prevent the sintering of the $\mathrm{Cu}$ crystallites and improve the activities of the copper catalysts, they are usually modified with $\mathrm{Al}_{2} \mathrm{O}_{3}$ [24], $\mathrm{ZrO}_{2}$ [74,86,83], $\mathrm{Cr}_{2} \mathrm{O}_{3}$ [24], $\mathrm{CeO}_{2}[24,48,50]$ and $\mathrm{TiO}_{2}$ [89].

\subsection{Support catalysts}

In order to operate a hydrogen fuel cell, the hydrogen could be obtained from the process with a high cost of energy expenditure. Number of issues pertaining to the catalyst such as other components (promoters), supports, precursors, and preparation methods have been studied [14]. In order to improve their catalytic activity, several approaches are reported in the literature.

The support materials used in catalyst preparation play a crucial role in determining the physical characteristics and performance of the catalysts as contained in Table 3 . Alumina is one of the best known catalyst-support materials frequently used in both research and industrial applications [24]. Cu catalysts deactivated during on-stream experiments. Addition of $\mathrm{Al}$ improved the catalyst stability but the methanol conversion rate reduced considerably. To avoid this inconvenience, we have employed $\mathrm{CuZnAl}$ ternary oxides obtained from thermal decomposition of $\mathrm{CuZnAl}$ hydroxycarbonates containing hydrotalcite as a major phase, since it is known that the nature of precursor and the method of preparation play an important role in the catalytic performance of CuZn based methanol synthesis catalysts [20,25]. CuZnAl mixed oxides derived from hydrotalcite precursors have already been demonstrated to be efficient catalysts for the synthesis of methanol at low pressure [22].

A number of researchers have reported positive effects from incorporating $\mathrm{ZrO}_{2}$ in copper catalysts as a promoter or support. Zirconium has recently emerged as a particularly interesting support material. $\mathrm{ZrO}_{2}$ presents special characteristics such as high fracture toughness, ionic conductivity, and stability even under reducing conditions. Moreover, the possession of both amphoteric and redox functions makes it appealing as a more suitable carrier for a number of catalytic applications [90].

$\mathrm{CuO}-\mathrm{CeO}_{2}$ mixed oxide catalysts have been recently proposed as a promising candidate for the selective removal of $\mathrm{CO}$ from reformate streams $[3,64,65]$. These catalysts are able to operate at a temperature range of 100-200 ${ }^{\circ} \mathrm{C}$ with almost ideal selectivity. Their performance is superior to that of Pt-group-based catalysts, since they are more active and remarkably more selective while operating at a lower reaction temperature [91].

$\mathrm{CeO}_{2}$ promoted catalysts have been rapidly developed in recent years [23]. $\mathrm{CeO}_{2}$ has the cubic fluorite structure and foreign cations, such as $\mathrm{Si}^{4+}, \mathrm{Th}^{4+}, \mathrm{Zr}^{4+}, \mathrm{Y}^{3+}, \mathrm{La}^{3+}, \mathrm{Sc}^{3+}, \mathrm{Mg}^{2+}, \mathrm{Ca}^{2+}$ and $\mathrm{Cu}^{2+}$ can be introduced into the $\mathrm{CeO}_{2}$ lattice and can improve the physical properties of the $\mathrm{CeO}_{2}$. High oxygen mobility, strong interaction with the supported metal (strong metal-support interaction) and the modifiable ability, render the $\mathrm{CeO}_{2}$-based materials very interesting for catalysis and as a support [11]. The high oxygen mobility, strong interaction with certain metals and the modifying ability make $\mathrm{CeO}_{2}$ to be a very interesting promoter for catalysts. Table 3 shows physicochemical properties of $\mathrm{Cu}$ and $\mathrm{Zn}$ based catalysts of some previous studies.

\subsection{Preparation methods of catalyst}

The method of preparation plays an important role in the structure and performance of methanol reforming catalysts [92]. The preparation method has a stronger influence on the mechanical stability of catalyst [41].

There are several methods for catalyst preparation such as Co-precipitation [11,46,51,87,83], Wetness impregnation [89], Impregnation [4,11], Wash coat [45], Oxalic coprecipitation [24,80], Aurichalcite precursor [11], Hydrotalcite precursor [11], Polyol Method [80].

$\mathrm{Wu} \&$ Chung [80], reported The sequence of methanol conversion for catalytic preparation method was oxalic co precipitation $>$ polyol method $>$ co precipitation, according to analysis of XRD spectrum, the $\mathrm{Cu}$ sizes calculated for oxalic co precipitation, polyol method, co precipitation were $17.5,36.5$ and $65.7 \mathrm{~nm}$, respectively. It is mean that the smaller $\mathrm{Cu}$ size resulted made the higher dispersion of $\mathrm{Cu}$ on the catalyst so that the methanol conversion was higher [80]. 


\section{$5.4 \mathrm{pH}$ of preparation catalyst}

$\mathrm{pH}$ has influent into methanol steam reforming, the particle size of catalyst increased with increasing $\mathrm{pH}$ value [24]. Kuo \& Wu [24], reported effect of $\mathrm{pH}$ for life time at reaction temperature of $200{ }^{\circ} \mathrm{C}$ on methanol reformation. The sequence of methanol conversion for the life time of $\mathrm{Cu} / \mathrm{ZnO} / \mathrm{Al}_{2} \mathrm{O}_{3}$ catalyst is $\mathrm{pH} 1>$ $\mathrm{pH} 5>\mathrm{pH} 3>\mathrm{pH} 7>\mathrm{pH} 9$, and concentration of $\mathrm{CO}$ was kept between 1000 and $4000 \mathrm{ppm}$ when the reaction temperature was $200{ }^{\circ} \mathrm{C}$. Especially, pH1 has good activity in methanol reforming [24].

\subsection{Temperature of preparation catalyst}

Precipitation temperature has influence to the size of catalyst particle. Zhang and coworkers [93], reported the stripping-precipitation approach could be explore to control particle agglomeration and size [93].The high dispersion of $\mathrm{Cu}$ resulted from the small crystallite size in the precipitate by slow formation at low temperature [94]. Kuo \& Wu [24], reported agglomeration of $\mathrm{Cu} / \mathrm{ZnO} / \mathrm{Al}_{2} \mathrm{O}_{3}$ catalysts apparently decrease from $25{ }^{\circ} \mathrm{C}$ to $-5{ }^{\circ} \mathrm{C}$ when the precipitation temperature of catalyst was gradually decreased. Because the $\mathrm{Cu}$ dispersion will be affected by Amount of agglomeration, the dispersion of $-5{ }^{\circ} \mathrm{C}$ is better [24].

\section{$5.6 \mathrm{O}_{2} / \mathrm{CH}_{3} \mathrm{OH}$ molar ratio}

Methanol conversion was higher with increasing $\mathrm{O}_{2} / \mathrm{CH}_{3} \mathrm{OH}$ molar ratio, However that the hydrogen production rate increases with decreasing $\mathrm{O}_{2} / \mathrm{CH}_{3} \mathrm{OH}$ molar ratio [4]. OSR reaction could be from endothermic to exothermic when the oxygen/methanol ratio in the feed increases. Hence it could offer an effective way to regulate the reaction temperature in the reactor and less heat exchange between cold and hot streams is required. This makes the reformer compacter especially important for transportation fuel cell applications [92].

Weidong and coworkers [20], reported when the $\mathrm{O}_{2} / \mathrm{CH}_{3} \mathrm{OH}$ ratio increases, the methanol conversion also increases. This increase are apparently relate to oxidative conversion. However, a related fact is that as $\mathrm{O}_{2} / \mathrm{CH}_{3} \mathrm{OH}$ ratio was decrease, the carrier (inert $\mathrm{N}_{2}$ in air) is also reduced [20].

Hyuun and coworkers [85], reported that a reduced copper-based catalyst was testing at different $\mathrm{O}_{2} / \mathrm{CH}_{3} \mathrm{OH}$ ratios. They have found that the copper-based catalyst can function significantly below the thermo neutral point of $0.23 \mathrm{O}_{2} / \mathrm{CH}_{3} \mathrm{OH}$ ratios. The change in enthalpy is accounting for by a much reduced exit temperature, which is cause by the highly active catalyst and the endothermic reactions taking place [85].

\section{$5.7 \mathrm{H}_{2} \mathrm{O} / \mathrm{CH}_{3} \mathrm{OH}$ molar ratio}

Methanol conversion and hydrogen production rate increase with increasing $\mathrm{H}_{2} \mathrm{O} / \mathrm{CH}_{3} \mathrm{OH}$ molar ratio [4]. Wu \& Chung [80], reported the methanol conversion was increase with increasing molar ratio of $\mathrm{H}_{2} \mathrm{O} / \mathrm{CH}_{3} \mathrm{OH}$ up to 1.2 , and then decrease. The methanol and water competed simultaneously with the active site of the catalyst. The trend of hydrogen production rate was similar to that of methanol conversion. $\mathrm{CO}_{2}$ selectivity was increased with increasing molar ratio of $\mathrm{H}_{2} \mathrm{O} / \mathrm{CH}_{3} \mathrm{OH}$. It is demonstrated that water-gas shift reaction was enhanced as the molar ratio $\mathrm{H}_{2} \mathrm{O} / \mathrm{CH}_{3} \mathrm{OH}$ increased [80].

\subsection{Weight Hourly Space Velocity (WHSV)}

Space velocity is also a crucial factor that can influence the catalyst activity and concentration profiles [95]. The hydrogen production rate is directly proportional to the WHSV of methanol [4]. It was found that lowering the feed rate to the radial flow reactor resulted in lower $\mathrm{CO}$ concentration in the reformate stream [82]. The methanol conversion and volumetric percentage of CO decreased when the WHSV increased [80].

Xinrong and coworkers [23] reported the effect of WHSV on the catalytic performance of $\mathrm{CeO}_{2}$ promoted catalysts. Methanol conversion and the outlet CO concentration decrease with increasing WHSV of methanol, and hydrogen yield have a maximum in the experiment conditions. On the other hand, WHSV of methanol does not affect the selectivity of $\mathrm{H} 2$, which remains around 99.9\% throughout the experiment.

\subsection{Carrier gas}

In general, carrier gas was used with inert gas, such as helium and nitrogen, to avoid gas reaction with methanol. However, the cost of carrier gas will increase in industrial application. Hence, if the carrier gas could be replaced with air, the system cost could be reduced, but methanol reformation would become partial oxidation or autothermal reaction [80]. Wu \& Chung [80] reported that using air to carry methanol is a good method and increases the reaction reactivity, which could result in a higher 
Table 4. Influence of catalyst compositions, temperature of calcinations, temperature of drying, temperature of reaction, $\mathrm{S} / \mathrm{M}, \mathrm{O} / \mathrm{M}$ on the performance of different $\mathrm{Cu}$ and $\mathrm{Zn}$ based catalysts for autotermal reforming reaction of methanol

\begin{tabular}{|c|c|c|c|c|c|c|c|c|c|c|c|c|}
\hline Catalyst & $\begin{array}{c}\text { Composition } \\
\left(w t^{\prime} \%\right)\end{array}$ & $\begin{array}{c}\mathbf{T}_{\mathrm{C}} \\
\left({ }^{\circ} \mathbf{C}\right)\end{array}$ & $\begin{array}{l}\mathbf{T}_{\mathrm{D}} \\
\left({ }^{\circ} \mathbf{C}\right)\end{array}$ & $\begin{array}{l}\mathbf{T}_{\mathrm{R}} \\
\left({ }^{\circ} \mathbf{C}\right)\end{array}$ & $\mathbf{S} / \mathbf{M}$ & $\mathrm{O} / \mathrm{M}$ & $\begin{array}{l}\mathrm{X}_{\mathrm{MeO}} \\
\text { н (\%) }\end{array}$ & $\begin{array}{l}\mathrm{H}_{2} \\
(\%)\end{array}$ & $\begin{array}{c}\text { CO } \\
\text { (ppm } \\
\text { ) }\end{array}$ & $\begin{array}{l}\text { TOS } \\
\text { (h) }\end{array}$ & $\mathrm{S}_{\mathrm{Co}}(\%)$ & $\begin{array}{c}\text { WHS } \\
\text { V } \\
\left(h^{-1}\right)\end{array}$ \\
\hline $\mathrm{Cu} / \mathrm{ZnO} / \mathrm{Al}_{2} \mathrm{O}_{3}[4]$ & - & - & - & 300 & 6.5 & 0.13 & 73 & - & 0 & - & 0.16 & - \\
\hline $\mathrm{Cu} / \mathrm{Zn} / \mathrm{Al}_{2} \mathrm{O}_{3}[24]$ & $15 / 15 / 5$ & 300 & 100 & 200 & 1.2 & 0.28 & 80.6 & 47 & 1500 & 35 & - & 7.27 \\
\hline $\mathrm{Cu} / \mathrm{Zn} / \mathrm{ZrO}{ }_{2}[24]$ & $15 / 15 / 5$ & 300 & 100 & 200 & 1.2 & 0.28 & 78.8 & 47.5 & 1500 & 35 & - & 7.27 \\
\hline $\mathrm{Cu} / \mathrm{Zn} / \mathrm{CeO}_{2}[24]$ & $15 / 15 / 5$ & 300 & 100 & 200 & 1.2 & 0.28 & 56 & 43 & 500 & 35 & - & 7.27 \\
\hline $\mathrm{Cu} / \mathrm{Zn} / \mathrm{Cr}_{2} \mathrm{O}_{3}[24]$ & $15 / 15 / 5$ & 300 & 100 & 200 & 1.2 & 0.28 & 67 & 45 & 4800 & 35 & - & 7.27 \\
\hline $\mathrm{Cu} / \mathrm{Zn} / \mathrm{Al}[45]$ & $40 / 50 / 10$ & 350 & 25 & 270 & 1.3 & - & 98 & $\begin{array}{c}73- \\
75\end{array}$ & - & - & $0.1-1.2$ & 10 \\
\hline $\begin{array}{l}\mathrm{Cu} / \mathrm{ZnO} / \mathrm{Al}_{2} \mathrm{O}_{3} \\
{[80]}\end{array}$ & $15 / 15 / 5$ & 300 & 120 & 240 & 1.5 & 0.15 & 97.6 & $57^{\mathrm{a}}$ & - & - & $0.04^{\mathrm{a}}$ & - \\
\hline $\mathrm{Cu} / \mathrm{Zn} / \mathrm{Al}$ [87] & $30 / 30 / 40$ & 400 & 110 & 280 & 1.5 & 0.15 & 60 & - & 9400 & - & - & - \\
\hline Cu/Zn/Al [87] & $30 / 20 / 50$ & 400 & 110 & 280 & 1.5 & 0.15 & 77 & - & 3400 & 75 & - & - \\
\hline $\mathrm{Cu} / \mathrm{Zn} / \mathrm{Ce} / \mathrm{Al}[87]$ & $30 / 25 / 5 / 40$ & 400 & 110 & 280 & 1.5 & 0.15 & 69 & - & 1400 & - & - & - \\
\hline $\mathrm{Cu} / \mathrm{Zn} / \mathrm{Ce} / \mathrm{Al}[87]$ & $30 / 20 / 10 / 40$ & 400 & 110 & 280 & 1.5 & 0.15 & 100 & - & 995 & 75 & - & - \\
\hline $\mathrm{Cu} / \mathrm{Zn} / \mathrm{Ce} / \mathrm{Al}[87]$ & $30 / 10 / 20 / 40$ & 400 & 110 & 280 & 1.5 & 0.15 & 90 & - & 1240 & 75 & - & - \\
\hline $\begin{array}{l}\mathrm{CuO} / \mathrm{ZnO} / \mathrm{Al}_{2} \mathrm{O}_{3} \\
{[83]}\end{array}$ & $30 / 60 / 10$ & 350 & 110 & 250 & 1.1 & 0.1 & 65.5 & - & - & 80 & 0.38 & 1.4 \\
\hline $\begin{array}{l}\mathrm{CuO} / \mathrm{ZnO} / \mathrm{Al}_{2} \mathrm{O}_{3} \\
{[83]}\end{array}$ & $40 / 50 / 10$ & 350 & 110 & 250 & 1.1 & 0.1 & 79.6 & - & - & 80 & 0.37 & 1.4 \\
\hline $\begin{array}{l}\mathrm{CuO} / \mathrm{ZnO} / \mathrm{Al}_{2} \mathrm{O}_{3} \\
{[83]}\end{array}$ & $50 / 40 / 10$ & 350 & 110 & 250 & 1.1 & 0.1 & 71.1 & - & - & 80 & 0.39 & 1.4 \\
\hline $\begin{array}{l}\mathrm{CuO} / \mathrm{ZnO} / \mathrm{Al}_{2} \mathrm{O}_{3} \\
{[83]}\end{array}$ & $60 / 30 / 10$ & 350 & 110 & 250 & 1.1 & 0.1 & 69.8 & - & - & 80 & 0.45 & 1.4 \\
\hline $\mathrm{ZnCr/Ti} \mathrm{[89]}$ & $\begin{array}{c}20 \% \mathrm{ZnO}_{-} \\
\mathrm{ZnCr}_{2} \mathrm{O}_{4} / \mathrm{TiO}_{2}\end{array}$ & 800 & 120 & 240 & 1.2 & 0.3 & $24.8^{\mathrm{i}}$ & $22.7^{\mathrm{i}}$ & - & 3 & $0.9^{\mathrm{i}} / 0.1^{\mathrm{s}}$ & - \\
\hline $\mathrm{ZnCr/Al}$ [89] & $\begin{array}{c}20 \% \mathrm{ZnO}_{-} \\
\mathrm{ZnCr}_{2} \mathrm{O}_{4} / \mathrm{Al}_{2} \mathrm{O}_{3}\end{array}$ & 800 & 120 & 240 & 1.2 & 0.3 & $\begin{array}{l}14.5^{\mathrm{s}} \\
89.2^{\mathrm{i}} \\
/ \\
56.8^{\mathrm{s}}\end{array}$ & $\begin{array}{c}24.7^{\mathrm{s}} \\
41.6^{\mathrm{i}} \\
/ \\
35.4^{\mathrm{s}}\end{array}$ & - & 20 & $\begin{array}{l}63.4^{\mathrm{i} /} \\
61.0^{\mathrm{s}}\end{array}$ & - \\
\hline $\mathrm{ZnCr/Ce} \mathrm{[89]}$ & $\begin{array}{c}20 \% \mathrm{ZnO}_{-} \\
\mathrm{ZnCr}_{2} \mathrm{O}_{4} \\
/ \mathrm{CeO}_{2}\end{array}$ & 800 & 120 & 240 & 1.2 & 0.3 & $\begin{array}{l}89.1^{\mathrm{i}} \\
I^{\prime} \\
67.4^{\mathrm{s}}\end{array}$ & $\begin{array}{l}51.8^{\mathrm{i}} \\
/ \\
48.4^{\mathrm{s}}\end{array}$ & - & 30 & $\begin{array}{l}7.8^{\mathrm{i} /} \\
5.9^{\mathrm{s}}\end{array}$ & - \\
\hline $\mathrm{ZnCr/Zr} \mathrm{[89]}$ & $\begin{array}{c}20 \% \mathrm{ZnO}_{-} \\
\mathrm{ZnCr}_{2} \mathrm{O}_{4} / \mathrm{ZrO}_{2}\end{array}$ & 800 & 120 & 240 & 1.2 & 0.3 & $\begin{array}{l}99.2^{\mathrm{i}} \\
/ \\
87.1 \mathrm{~s}\end{array}$ & $\begin{array}{l}51.9^{\mathrm{i}} \\
/ / \\
497^{\mathrm{s}}\end{array}$ & - & 50 & $\begin{array}{c}18.2^{\mathrm{i} /} \\
19.9^{\mathrm{s}}\end{array}$ & - \\
\hline $\mathrm{ZnCr} / \mathrm{CeZr41}$ [89] & $\begin{array}{c}20 \% \mathrm{ZnO}_{-} \\
\mathrm{ZnCr}_{2} \mathrm{O}_{4} / \mathrm{CeO}- \\
\mathrm{ZrO}_{2} \\
(\mathrm{Ce} / \mathrm{Zr}=4 / 1)\end{array}$ & 800 & 120 & 240 & 1.2 & 0.3 & $\begin{array}{c}87.1^{\mathrm{s}} \\
99.9^{\mathrm{i}} \\
/ \\
99.7^{\mathrm{s}}\end{array}$ & $\begin{array}{l}49.7^{\mathrm{s}} \\
52.2^{\mathrm{i}} \\
/^{\prime} \\
52.8^{\mathrm{s}}\end{array}$ & - & 67 & $\begin{array}{c}10.7^{\mathrm{i} /} \\
4.1^{\mathrm{s}}\end{array}$ & - \\
\hline $\mathrm{ZnCr}$ [89] & $\mathrm{ZnO}-\mathrm{ZnCr}_{2} \mathrm{O}_{4}$ & 800 & 120 & 240 & 1.2 & 0.3 & $\begin{array}{l}99.7^{\mathrm{i}} \\
/ \\
70.7^{\mathrm{s}} \\
\end{array}$ & $\begin{array}{l}51.8^{\mathrm{i}} \\
/ \\
44.6^{\mathrm{s}}\end{array}$ & - & 58 & $\begin{array}{l}18.9^{\mathrm{i} /} \\
15.0^{\mathrm{s}}\end{array}$ & - \\
\hline
\end{tabular}

$\mathrm{T}_{\mathrm{C}}=$ Temperature of Calcinations; $\mathrm{T}_{\mathrm{R}}=$ Temperature of reaction; $\mathrm{T}_{\mathrm{D}}=$ Temperature of drying; $\mathrm{X}_{\mathrm{MeOH}}=\mathrm{Methanol}$ conversion; TOS =Time on stream; $\mathrm{S}_{\mathrm{CO}}=$ Carbon dioxide Selectivity; $\mathrm{i}=$ Initial; $\mathrm{s}=$ Shutdown; $\mathrm{a}=\mathrm{vol}_{\%}$; $\mathrm{H}_{2}=\mathrm{Yield}$ of hydrogen; $\mathrm{CO}=$ Yield of carbon monoxide; S/M = Water per methanol ratio; O/M; Oxygen per methanol ratio; WHSV = Weight hourly space velocity.

volumetric percentage of hydrogen $(>50 \%)$ and lower volumetric percentage of $\mathrm{CO}(<500 \mathrm{ppm})$ [80].

Weidong and oworkers [80], reported during the reaction process, the carrier gas also affects heat transfer, and the heat transfer speed could decrease due to lower flow rate of carrier gas. Heat transfer affects the reaction due to endothermic nature of steam reforming reaction and exothermic nature of partial oxidation [20]. 


\subsection{Temperature of reaction}

The long-term activity of catalyst is essential for the automobiles operated by PEM fuel cell to avoid the frequent replacement of reformer catalysts [49] and reaction temperature should be a lower for efficiency of the process.

For all tested catalysts high selectivity to $\mathrm{CO}_{2}$ could be achieve only at very low catalyst temperatures where methanol conversion and hydrogen production rates were prohibitively low [82].

Udani and coworkers [48], reported the CO selectivity increased with increasing reaction temperature but the $\mathrm{CO}$ concentration was always significantly lower than the equilibrium CO concentration [48].

$\mathrm{Wu} \&$ Chung [80], reported when the temperature is high and methanol retention time is high (The amount of the catalyst is greater), one can readily observe these reactions. Therefore, increasing the amount of the catalyst is not necessary to obtain a good methanol reformation [80].

Xinrong and coworkers [23], reported methanol conversion and hydrogen yield increase with increasing reaction temperature, while methanol is convert almost completely into $\mathrm{H}_{2}$, $\mathrm{CO}_{2}$, and $\mathrm{CO}$ up to $280{ }^{\circ} \mathrm{C}$. In the temperature range of $180-280{ }^{\circ} \mathrm{C}$, hydrogen selectivity remains almost unchanged, and the outlet $\mathrm{CO}$ concentration is less than $0.4 \mathrm{~mol} \%$ [23].

Based on some research previously in Table 3, none of the researchers conducted a step precipitation with the same temperature of drying and temperature of calcinations. The effect of drying temperature, calcinations temperature to catalyst activity is interesting to further study.

Table 4 shows that the autothermal reforming methanol influenced by temperature of calcinations and temperature of drying. Therefore, the effect of temperature of calcinations and temperature of drying to catalyst activity is interesting to further study.

\section{Conclusions}

The results of this resume were to describe autothermal reforming reaction of methanol to hydrogen production using $\mathrm{Cu}$-based catalysts along with the process parameter.

The author gives a conclusion that methanol is very promising as a source of raw material for hydrogen production. Methanol easy to produced from renewable sources, high $\mathrm{H} / \mathrm{C}$ ratio, more efficient as raw material for hydrogen.

Autothermal methanol reforming reaction method is also quite promising as a composite of partial oxidation methanol and methanol steam reforming. The autothermal reforming method is better than the other methods, Based on the reaction temperature is low, high methanol conversion and high yield of hydrogen. However, weaknesses in the high yield of $\mathrm{CO}$ are produce.

Catalyst, promoter catalyst, support catalysts,Preparation catalyst methods, $\mathrm{pH}$ on precipitation catalyst, temperature of precipitation catalyst, $\mathrm{O}_{2} / \mathrm{CH}_{3} \mathrm{OH}$ molar ratio, WHSV, carrier gas, $\mathrm{H}_{2} \mathrm{O} / \mathrm{CH}_{3} \mathrm{OH}$, and temperature of reaction are several factors that influence the success of the hydrogen production process by autothermal reforming methanol method. Cu-based catalyst is better than the other catalysts. $\mathrm{Cu}$ has a higher activity and Low in producing CO. The effect of temperature of calcinations and temperature of drying to catalyst activity is interesting to further study.

\section{References}

[1] Suparoek, H., and Pisanu, T. (2002). Effect of Preparation of $\mathrm{Cu} / \mathrm{Zn}$ over $\mathrm{Al}_{2} \mathrm{O}_{3}$ Catalysts for Hydrogen Production from Methanol Reforming. Suranaree Journal of Science Technology 16(2): 103-112.

[2] Abdullah, M., Khairurrijal, N.F.A, Marully, A. R., Sanny, M. (2010). Design of Steam Reforming Reactor for Converting Methanol into Hydrogen Using an Ultrasonic Nebulizer as Liquid Feeder and Polymer Liquid Processed $\mathrm{CuO} / \mathrm{ZnO} / \mathrm{Al}_{2} \mathrm{O}_{3}$ Particles as Catalyst. Journal of Sustainable Energy and Environment 1: 11-15.

[3] Cheng, W.H. (1999). Development of Methanol Decomposition Catalysts for Production of $\mathrm{H}_{2}$ and CO. Accounts of Chemical Research 32: 685691.

[4] Yong, S.T., Hidajat, K., Kawi, S. (2004). Reaction study of autothermal steam reforming of methanol to hydrogen use a novel nano CuZnAlcatalyst. Journal of Power Sources 131 : 91-95.

[5] Ersoza, A., Olguna, H., Ozdoganb, S., Gungora, C., Akguna, F., Tirıs, M. (2003). Autothermal reforming as a hydrocarbon fuel processing option for PEM fuel cell. Journal of Power Sources 118 : 384-392.

[6] Kruger, P. (2001). Electric Power Requirement for Large-scale Production of Hydrogen Fuel for the World Vehicle Fleet. International Journal of Hydrogen Energy 26 : 1137-1147.

[7] Chin, Y.H., Robert, D., Hu, J., Alice, C.D., Wang, 
Y. (2002). Steam reforming of methanol over highly active $\mathrm{Pd} / \mathrm{ZnO}$ catalyst. Catalysis Today $77: 79-88$.

[8] Yoshitsugu, K., Suzuki, K., Kazuhiro, I., Megumi, F., Toshio, S., Yasuaki, Y., Hiroaki, K. H. (2002). Hydrogen generation using sodium borohydride solution and metal catalyst coated on metal oxide. International Journal of Hydrogen Energy 27 : 1029 - 1034.

[9] Nunticha, K., Supaporn, T., Apichai, T., Navadol, L. (2006). Study of Hydrogen Production from Natural Gas by Autothermal Reforming. Asean Journal on Energy and Environment 7(4) : 434-443

[10] Kim, J.H., Lee, H., Han, S.C., Kim, H.S., Song, M.S., Lee, J.S. (2004). Production of hydrogen from sodium borohydride in alkaline solution: development of catalyst with high performance. International Journal of Hydrogen Energy 29: $263-267$.

[11] Yanyong, L., Takashi, H., Kunio, S., Satoshi, H., Tatsuo, T., Tomoko, I., Mikio, K. (2002). Highly active copper/ceria catalysts for steam reforming of methanol. Applied Catalysis A: General 223 : 137-145.

[12] Diagne, C., Idriss, H., Kiennemann, A. (2002). Hydrogen production by ethanol reforming over $\mathrm{Rh}=\mathrm{CeO}_{2}-\mathrm{ZrO}_{2}$ catalysts. Catalysis Communications 3: 565-571.

[13] Stephen, S., Peter, D., Alexander, S., Mukasyan, E.W. (2008). A Novel Combustion Synthesis Preparation of $\mathrm{CuO} / \mathrm{ZnO} / \mathrm{ZrO}_{2} / \mathrm{Pd}$ for Oxidative Hydrogen Production from Methanol. Catalysis Letters 121 : 189-198.

[14] Bichon, P., Asheim, M. Jordal, A., Sperle, T., Fathi, M., Holmen, A., Blekkan, E.A. (2007). Hydrogen from methanol steam reforming over $\mathrm{Cu}$-based catalysts with and without $\mathrm{Pd}$ promotion. International Journal of Hydrogen Energy 32 : 1799 - 1805.

[15] Nádia, R.C.F.M., Roberta, C.P.R.e.R.P.S.P. (2002). Performance of catalysts with $\mathrm{Nb}_{2} \mathrm{O}_{5}$ for hydrogen production from ethanol steam reforming. Maringá 24 (6) : 1637-1642.

[16] Sharaf, A.M., and El-Sayed, M.A.H. (2009). Dynamic Control of Fuel Cell Powered Water Pumping Station. Paper presented in International Conference. ICREPQ-2009. April 15-17. European Association for the Development of Renewable Energies, Environment and Power Quality. Valencia. Spain.

[17] Zahira, Y., Satheesh, K.N.M., Ibrahim, M.A., Daud, W.R.W., Kadhum, A.A.H. (2009). Multi Composition $\mathrm{Cu}-\mathrm{Zn}-\mathrm{Al}$ Catalyst Supported on ZSM-5 for Hydrogen Production. European Journal of Scientific Research 28 (1) : 141-154.
[18] Sáa, S., Silva, H., Lúcia, B., José, M.S., Adélio, M. (2010). Catalysts for methanol steam reforming - A review. Applied Catalysis B: Environmental 99 : 43-57.

[19] Chin, Y.H., Wang, Y., Dagle, R.A., Li, X.S. (2003). Methanol steam reforming over Pd/ZnO: Catalyst preparation and pretreatment studies. Fuel Processing Technology 83 : 193- 201.

[20] Weidong, G., Shen, J.P., Song, C. (2003). Hydrogen Production From Integrated Methanol Reforming Over $\mathrm{Cu}-\mathrm{ZnO} / \mathrm{Al}_{2} \mathrm{O}_{3}$ and $\mathrm{Pt} / \mathrm{Al}_{2} \mathrm{O}_{3}$ Catalysts For PEM Fuel Cells. Preprint Papers American Chemical Society, Division of Fuel Chemistry 48(2) : 804 .

[21] Elise, S.B., Subramani,V., Chunshan, S. (2005). Nano-structured $\mathrm{CeO}_{2}$ supported $\mathrm{Cu}-\mathrm{Pd}$ bimetallic catalysts for the oxygen-assisted water-gas-shift reaction. Catalysis Today 99: 347-357.

[22] Velu, S., Suzuki, K., Osaki, T. (1999). Selective production of hydrogen by partial oxidation of methanol over catalysts derived from CuZnAllayered double hydroxides. Catalysis Letters 62 : 159-167.

[23] Xinrong, Z., Pengfei, S. (2003). Production of hydrogen by steam reforming of methanol on $\mathrm{CeO}_{2}$ promoted $\mathrm{Cu} / \mathrm{Al}_{2} \mathrm{O}_{3}$ catalysts. Journal of Molecular Catalysis A: Chemical 194 : 99-105.

[24] Kuo, C.H., Wu, H.S. (2009). Methanol reforming reaction carried out at low temperature using $\mathrm{Cu} / \mathrm{ZnO} / \mathrm{Al}_{2} \mathrm{O}_{3}$, Derivative, Master Thesis, Yuan Ze University.

[25] Chuang, C.C., Chen, Y.H., Jeffrey, D.W., Yua, C.C., Liu, Y.C., Lee, C.H. (2008). Optimal design of an experimental methanol fuel reformer. International Journal of Hydrogen Energy 33 : $7062-7073$.

[26] James, L., Andrew, D. (2003). Fuel Cells System Explained, John Wiley and Sons Ltd. The Atrium. Southern Gate, Chichester, West Sussex PO19 8SQ. England.

[27] Larminie, J., Dicks, A. (2003). Fuel Cell Systems Explained Second Edition. John Wiley and Sons Ltd. The Atrium, Southern Gate, Chichester, West Sussex PO19 8SQ. England.

[28] Lee, J.K., Ko, J.B., Kim, D.H. (2004). Methanol steam reforming over $\mathrm{Cu} / \mathrm{ZnO} / \mathrm{Al}_{2} \mathrm{O}_{3}$ catalyst: kinetics and effectiveness factor. Applied Catalysis A: General 278: 25-35.

[29] Youngjoon, S., Wonseok, P., Jonghwa, C., Jongkuen, P. (2007). Evaluation of the high temperature electrolysis of steam to produce hydrogen. International Journal of Hydrogen Energy 32 : 1486 - 1491.

[30] Dubey, P.K., Sinha, A.S.K., Talapatra, S., 
Koratkar, N., Ajayan, P.M., Srivastava, O.N. (2010). Hydrogen generation by water electrolysis using carbon nanotube anode. International Journal of Hydrogen Energy 35: 3945-3950.

[31] Mingyi, L., Bo, Y., Jingming, X., Jing, C. (2008). Thermodynamic analysis of the efficiency of high-temperature steam electrolysis system for hydrogen production. Journal of Power Sources 177: 493-499.

[32] Abanades, S., Charvin, P., Flamant, G., Neveu, P. (2006). Screening of water-splitting thermochemical cycles potentially attractive for hydrogen production by concentrated solar energy. Energy 31: 2805-2822.

[33] Abanades, S., Charvin, P., Lemont, F., Flamant, G. (2008). Novel two-step $\mathrm{SnO}_{2} / \mathrm{SnO}$ watersplitting cycle for solar thermochemical production of hydrogen. International Journal of Hydrogen Energy 33 : 6021-6030.

[34] Nobuyuki, G., Tomoki, H., Shingo, T., Tatsuya, K. (2008). Thermochemical two-step watersplitting for hydrogen production using Fe-YSZ particles and a ceramic foam device. Energy 33 : 1407- 1416 .

[35] Panagiotis, L. (2011). Production of electricity and hydrogen by photocatalytic degradation of organic wastes in a photoelectrochemical cell The concept of the Photofuelcell: A review of a re-emerging research field. Journal of Hazardous Materials 185 : 575-590.

[36] Maria, A., Panagiotis, B., Nikoleta, S., Panagiotis, L. (2008). Hydrogen and electricity generation by photoelectrochemical decomposition of ethanol over nanocrystalline titania. International Journal of Hydrogen Energy 33 : 5045-5051.

[37] Mishra, P.R., Shukla, P.K., Singh, A.K., Srivastava, O.N. (2003). Investigation and optimization of nanostructured $\mathrm{TiO}_{2}$ photoelectrode in regard to hydrogen production through photoelectrochemical process. International Journal of Hydrogen Energy 28: 1089 - 1094.

[38] Seichang, O., Nama, W.H., Sarper, J., Cho, S.J., Lee, C.H., Yoon, J. (2011). Photoelectrochemical hydrogen production with concentrated natural seawater produced by membrane process. Solar Energy 85: 2256-2263.

[39] Eroglu, E., Anastasios, M. (2011). Photobiological hydrogen production: Recent advances and state of the art. Bioresource Technology 102 : 8403-8413.

[40] Chitralekha, N.D.J., Jose, G., Lindblad, P., Thorsten, H., Stig, A., Borgvang, K.S., Debabrata, D. (2010). Recent trends on the development of photobiological processes and photobioreactors for the improvement of hydrogen production. International Journal of Hydrogen Energy 35 : 10218-10238.

[41] Benemann, J.R. (1997). Feasibility Analysis of Photobiological Hydrogen Production. International Journal of Hydrogen Energy 22 (10/11) : 979-987.

[42] Jorge, A.P.L., Vasilios, I.M. (2011). Natural gas based hydrogen production with zero carbon dioxide emissions. International Journal of Hydrogen Energy 36: 12853-12868.

[43] Pasquale, C., Fortunato, M. (2009). Natural gas and biofuel as feedstock for hydrogen production on $\mathrm{Ni}$ catalysts. Journal of Natural Gas Chemistry $18:$ 9-14.

[44] Sheldon, H.D.L., Daniel, V.A., Shabbir, A., Steven, G.C., Todd, L.H. (2005). Hydrogen from natural gas: part I-autothermal reforming in an integrated fuel processor. International Journal of Hydrogen Energy 30 : 829-842.

[45] Lin, K.S., Pan, C.Y., Sujan, C., Tu, M.T., Hong, W.T., Yeh, C.T. (2011). Hydrogen Generation Using a $\mathrm{CuO} / \mathrm{ZnO}-\mathrm{ZrO}_{2}$ Nanocatalyst for Autothermal Reforming of Methanol in a Microchannel Reactor. Molecules 16 : 348-366.

[46] Raphael, O.I., Narendra, N.B. (1994) Production of Hydrogen from Methanol, 2, Experimental Studies, Industrial Engineering and Chemistry Research 33 : 2056-2065.

[47] Xuelun, H., Suzhen, R. (2008). Selective hydrogen production from methanol oxidative steam reforming over $\mathrm{Zn}-\mathrm{Cr}$ catalysts with or without $\mathrm{Cu}$ loading. International Journal of Hydrogen Energy 33: 700-708.

[48] Udani, P.P.C., Gunawardana, P.V.D.S., Hyun, C.L., Dong, H.K. (2009). Steam reforming and oxidative steam reforming of methanol over $\mathrm{CuO}-\mathrm{CeO}_{2}$ catalysts. International Journal of Hydrogen Energy 34 : 7648-7655.

[49] Patel, S., Pant, K.K. (2006). Activity and stability enhancement of copper-alumina catalysts using cerium and zinc promoters for the selective production of hydrogen via steam reforming of methanol. Journal of Power Sources $159: 139-143$.

[50] Wenjuan, S., Zhaochi, F., Zhonglai, L., Jing, Z., Wenjie, S., Can, L. (2004). Oxidative steam reforming of methanol on $\mathrm{Ce}_{0.9} \mathrm{Cu}_{0.1} \mathrm{O}_{\mathrm{Y}}$ catalysts prepared by deposition-precipitation, coprecipitation, and complexation-combustion methods. Journal of Catalysis 228 : 206-217.

[51] Gang, H., Liaw, B.J., Jhang, C.J., Chen, Y.Z. (2009). Steam reforming of methanol over $\mathrm{CuO} / \mathrm{ZnO} / \mathrm{CeO}_{2} / \mathrm{ZrO}_{2} / \mathrm{Al}_{2} \mathrm{O}_{3}$ catalysts. Applied Catalysis A: General 358 : 7-12. 
[52] Chein, R.Y., Chen, L.C., Chen, Y.C., Chung, J.N. (2009). Heat transfer effects on the methanol-steam reforming with partially filled catalyst layers. International Journal of Hydrogen Energy 34 : 5398-5408.

[53] Bergamaschi, V.S., Carvalho, F.M.S. (2008). Hydrogen Production by Ethanol Steam Reforming Over $\mathrm{Cu}$ and $\mathrm{Ni}$ Catalysts Supported on $\mathrm{ZrO}_{2}$ and $\mathrm{Al}_{2} \mathrm{O}_{3}$ Microspheres. Materials Science Forum 591-593: 734-739.

[54] Albert, C., Gerons, M.S., Fabien, G., Jordi, L. (2008). Autothermal generation of hydrogen from ethanol in a microreactor. International Journal of Hydrogen Energy 33 : 1827-1833.

[55] Yu, Y., Jianxin, M., Fei, W. (2006). Production of hydrogen by steam reforming of ethanol over a $\mathrm{Ni} / \mathrm{ZnO}$ catalyst. International Journal of Hydrogen Energy 31: 877-882.

[56] Yu, C.Y., Lee, D.W., Park, S.J., Lee, K.Y., Lee, K.H. (2009). Study on a catalytic membrane reactor for hydrogen production from ethanol steam reforming. International Journal of Hydrogen Energy 34 : 2947-2954.

[57] Weijie, C., Fagen, W., Andre, V., Claude, D., Yves, S., Wenjie, S., Claude, M. (2010). Hydrogen production from ethanol steam reforming lin a micro-channel reactor. International Journal of Hydrogen Energy 35: 1152-1159.

[58] Fagen, W., Weijie, C., Helene, P., Yves, S., Claude, D., Claude, M., Wenjie, S. (2011). Hydrogen production from ethanol steam reforming over $\mathrm{Ir} / \mathrm{CeO}_{2}$ catalysts: Enhanced stability by $\mathrm{PrOx}$ promotion. International Journal of Hydrogen Energy 36 : 3566-3574.

[59] Mohamed, H.A.A., Fatthy, M.M., Abdel, W.E.E.E. (2011). Hydrogen production from rotten dates by sequential three stages fermentation. International Journal of Hydrogen Energy 36 : 3518-3527.

[60] Li, D., Yuan, Z., Sun, Y., Kong, X., Zhang, Y. (2009). Hydrogen production characteristics of the organic fraction of municipal solid wastes by anaerobic mixed culture fermentation. International Journal of Hydrogen Energy 34 : $812-820$.

[61] Georgia, A., Hariklia, N.G., Ioannis, V.S., Gerasimos, L. (2010). Influence of $\mathrm{pH}$ on fermentative hydrogen production from sweet sorghum extract. International Journal of Hydrogen Energy 35 : 1921-1928.

[62] Fikret, K., Ebru, C.C. (2011). Hydrogen gas production from olive mill wastewater by electrohydrolysis with simultaneous COD removal. International Journal of Hydrogen Energy 36 : 3457-3464.
[63] Ilgi, K.K., Fikret, K., Rukiye, O., Hidayet, A. (2009). Bio-hydrogen production from acid hydrolyzed wheat starch by photo-fermentation using different Rhodobacter sp. International Journal of Hydrogen Energy 34 : 2201-2207.

[64] Stefan, R., Frederic, V., Truonga, T.B., Takashi, S., Tomohisa, W., Hiroshi, A., Hideo, S. (2009). Catalytic reforming of gasoline to hydrogen: Kinetic investigation of deactivation processes. International Journal of Hydrogen Energy 34 : 8023-8033.

[65] Kiyoshi, O., Yukio, S., Sakae, T. (2002). Production of hydrogen from gasoline range alkanes with reduced $\mathrm{CO}_{2}$ emission. International Journal of Hydrogen Energy 27 : 11-18.

[66] Agrell, J., Birgersson, H., Boutonnet, M., Melián, C., Navarro, R.M., Fierro, J.L.G. (2003). Production of hydrogen from methanol over $\mathrm{Cu} / \mathrm{ZnO}$ catalysts promoted by $\mathrm{ZrO}_{2}$ and $\mathrm{Al}_{2} \mathrm{O}_{3}$. Journal of Catalysis 219 : 389-403.

[67] Dauenhauer, P.J., Salge, J.R., Schmidt, L.D. (2006). Renewable hydrogen by autothermal steam reforming of volatile carbohydrates. Journal of Catalysis 244 : 238-247.

[68] Liao, P.H., Yang, H.M. (2008). Preparation of Catalyst $\mathrm{Ni}-\mathrm{Cu} / \mathrm{CNT}$ s by Chemical Reduction with Formaldehyde for Steam Reforming of Methanol. Catalysis Letters 121 : 274-282.

[69] Lindström, B., Agrell, J., Pettersson, L.J. (2003). Combined methanol reforming for hydrogen generation over monolithic catalysts. Chemical Engineering Journal 93 : 91-101.

[70] Lindstrom, B., Pettersson, L.J. (2001). Hydrogen generation by steam reforming of methanol over copper-based catalysts for fuel cell applications. International Journal of Hydrogen Energy 26 : 923-933.

[71] Christopher, B.J., Erdogan, G. (2004). Hydrogen production from methanol decomposition over $\mathrm{Pt} / \mathrm{Al}_{2} \mathrm{O}_{3}$ and ceria promoted $\mathrm{Pt} / \mathrm{Al}_{2} \mathrm{O}_{3}$ catalysts. Catalysis Communications 5 : 431-436.

[72] Michael, K., Theodore, K., John, K., David, C., Shabbir, A. (2002). Catalytic Autothermal Reforming Of Hydrocarbon Fuels For Fuel Cells, Prepared for presentation at the 2002 Spring Meeting. New Orleans. LA March 10-14. Fuel Processing Session II.

[73] Papavasiliou, J., Avgouropoulos, G., Ioannides, T. (2004). Production of hydrogen via combined steam reforming of methanol over $\mathrm{CuO}-\mathrm{CeO}_{2}$ catalysts. Catalysis Communications 5 : 231235.

[74] Hernández, R.P., Martínez, A.G., Wing, C.E.G. (2007). Effect of $\mathrm{Cu}$ loading on $\mathrm{CeO}_{2}$ for hydrogen production by oxidative steam 
reforming of methanol. International Journal of Hydrogen Energy 32 : 2888-2894.

[75] Gunawardana, P.V.D.S., Lee, H.C., Kim, D.H. (2009). Performance of copper-ceria catalysts for water gas shift reaction in medium temperature range. International Journal of Hydrogen Energy 34: 1336-1341.

[76] Gines, M.J.L., Marchi, A.J., Apestegufa, C.R. (1997). Kinetic study of the reverse water-gas shift reaction over $\mathrm{CuO} / \mathrm{ZnO} / \mathrm{Al}_{2} \mathrm{O}_{3}$ catalysts. Applied Catalysis A: General 154 : 155-171.

[77] Nobuhiro, I., Tomoyuki, M., Wataru, N., Masahiko, A., Nobutsune, T. (2003). Effect of Zn addition to supported $\mathrm{Pd}$ catalysts in the steam reforming of methanol. Applied Catalysis A: General 248 : 153-160.

[78] Yoshinori, S., Ito, S.I., Kameoka, S., Tomishige, K., Kunimori, K. (2004). Comparative study between $\mathrm{Zn}-\mathrm{Pd} / \mathrm{C}$ and $\mathrm{Pd} / \mathrm{ZnO}$ catalysts for steam reforming of methanol. Applied Catalysis A: General 267 : 9-16.

[79] Easwar, S.R., Shyamal, B.K., Thompson, L.T. (2005). Methanol steam reforming over $\mathrm{Pd} / \mathrm{ZnO}$ and $\mathrm{Pd} / \mathrm{CeO}_{2}$ catalysts. Applied Catalysis A: General 289 : 153-162.

[80] Wu, H.S., Chung, S.C. (2007). Kinetics of Hydrogen Production of Methanol Reformation Using $\mathrm{Cu} / \mathrm{ZnO} / \mathrm{Al}_{2} \mathrm{O}_{3}$ catalyst. Journal of Combinatorial Chemistry 9 : 990-997.

[81] Turco, M., Bagnasco, G., Cammarano, C., Senese, P., Costantino, U., Sisani, M. (2007). $\mathrm{Cu} / \mathrm{ZnO} / \mathrm{Al}_{2} \mathrm{O}_{3}$ catalysts for oxidative steam reforming of methanol: The role of $\mathrm{Cu}$ and the dispersing oxide matrix. Applied Catalysis B: Environmental 77 : 46-57.

[82] Lyubovsky, M., Roychoudhury, S. (2004). Novel catalytic reactor for oxidative reforming of methanol. Applied Catalysis B: Environmental 54 : 203-215.

[83] Chang, C.C., Chang, C.T., Chiang, S.J., Liaw, B.J., Chen, Y.Z. (2010). Oxidative steam reforming of methanol over $\mathrm{CuO} / \mathrm{ZnO} / \mathrm{CeO}_{2} / \mathrm{ZrO}_{2} / \mathrm{Al}_{2} \mathrm{O}_{3} \quad$ catalysts. International Journal of Hydrogen Energy 35 : 7675-7683.

[84] Chen, G., Li, S., Li, H., Jiao, F., Yuan, Q. (2007). Methanol oxidation reforming over a $\mathrm{ZnO}$ $\mathrm{Cr}_{2} \mathrm{O}_{3} / \mathrm{CeO}_{2}-\mathrm{ZrO}_{2} / \mathrm{Al}_{2} \mathrm{O}_{3}$ catalyst in a monolithic reactor. Catalysis Today 125 : 97-102.

[85] Yoon, H.C., Paul, A.E., Kim, H.M. (2008). Lowering the $\mathrm{O}_{2} / \mathrm{CH}_{3} \mathrm{OH}$ ratio in autothermal reforming of methanol by using a reduced copper-based catalyst. International Journal of Hydrogen Energy 33: 6619-6626.
[86] Perez, H.R., Mondragon, G.G., Mendoza, A.D., Palacios, J., Angeles, C.C., Arenas, A.J. (2008). Synthesis and characterization of bimetallic $\mathrm{Cu}-$ $\mathrm{Ni} / \mathrm{ZrO}_{2}$ nanocatalysts: $\mathrm{H}_{2}$ production by oxidative steam reforming of methanol. International Journal of Hydrogen Energy 33 : 4569-4576.

[87] Patel, S., Panta, K.K. (2007). Selective production of hydrogen via oxidative steam reforming of methanol using $\mathrm{Cu}-\mathrm{Zn}-\mathrm{Ce}-\mathrm{Al}$ oxide catalysts. Chemical Engineering Science 62 : 5436-5443.

[88] Liu, S., Takahashi, K., Eguchi, H., Uematsu, K. (2007). Hydrogen production by oxidative methanol reforming on $\mathrm{Pd} / \mathrm{ZnO}$ : Catalyst preparation and supporting materials. Catalysis Today 129 : 287-292.

[89] Liu, N., Yuan, Z., Wang, C., Wanga, S., Zhanga, C., Wanga, S. (2008). The role of $\mathrm{CeO}_{2}-\mathrm{ZrO}_{2}$ as support in the $\mathrm{ZnO}-\mathrm{ZnCr}_{2} \mathrm{O}_{4}$ catalysts for autothermal reforming of methanol. Fuel Processing Technology 89 : 574-581.

[90] Wang, L.C., Liu, Q., Chen, M., Liu, Y.M., Cao, Y., He, H.Y., Fan, K.N. (2007). Structural Evolution and Catalytic Properties of Nanostructured $\mathrm{Cu} / \mathrm{ZrO}_{2}$ Catalysts Prepared by Oxalate Gel-Coprecipitation Technique, Journal of Physical Chemistry C. 111: 16549-16557.

[91] Avgouropoulos, G., Ioannides, T. (2003). Selective $\mathrm{CO}$ oxidation over $\mathrm{CuO}-\mathrm{CeO}_{2}$ catalysts prepared via the urea-nitrate combustion method. Applied Catalysis A: General 244 :155167.

[92] Honga, X., Ren, S. (2008). Selective hydrogen production from methanol oxidative steam reforming over $\mathrm{Zn}-\mathrm{Cr}$ catalysts with or without $\mathrm{Cu}$ loading. International Journal of Hydrogen Energy 33 : 700-708.

[93] Zhang, D.X., Xu, H., Liao, Y.Z., Li, H.S., Yang, X.J. (2009). Synthesis and Characterisation of Nano-Composite Copper Oxalate Powders by a Surfactant-Free Stripping-Precipitation Process. Powder Technology 189 : 404-408.

[94] Kawamura, Y., Yamamoto, K. (2005). Preparation of $\mathrm{Cu} / \mathrm{ZnO} / \mathrm{ZrO}_{2} / \mathrm{Al}_{2} \mathrm{O}_{3}$ Catalyst for a Micro Methanol Reformer. Journal of Power Sources. 150: 20-26.

[95] Wang, C., Liu, N., Pan, L., Wang, S., Yuan, Z., Wang, S. (2007). Measurement of concentration profiles over $\mathrm{ZnO}-\mathrm{Cr}_{2} \mathrm{O}_{3} / \mathrm{CeO}_{2}-\mathrm{ZrO}_{2}$ monolithic catalyst in oxidative steam reforming of methanol. Fuel Processing Technology 88 : 6571. 